\title{
Energy and Environmental Assessment of Straw Production for Power Generation
}

\author{
Oleg Bazaluk ${ }^{1, *}$, Valerii Havrysh ${ }^{2}$ and Vitalii Nitsenko ${ }^{3}$ \\ ${ }^{1}$ Belt and Road Initiative Centre for Chinese-European studies, Guangdong University of Petrochemical Technology, 525000 Maoming, \\ China \\ ${ }^{2}$ Department of Tractors and Agricultural Machinery, Operating and Maintenance, Mykolayiv National Agrarian University, 54020 \\ Mykolaiv, Ukraine \\ ${ }^{3}$ Department of Economics and Finance, Odesa National Maritime University, 65029 Odesa, Ukraine
}

\begin{abstract}
Agricultural residues, including straw, are important energy feedstock for electricity generation. This study aims to develop a model for energy and environmental assessment of straw production, taking into account its life cycle. The proposed mathematical model allows us to distribute input energy (into any crop production) and emit carbon dioxide (during crop production) between grain and straw formation. It takes into account direct energy input (fuels, electricity, etc.), indirect energy input (fertilizer, herbicide, etc.), and energy required in manufacturing agricultural tractors and implements. It has been found that straw formation consumes from 41 to $66 \%$ of the total energy input and $\mathrm{CO}_{2}$ emissions.
\end{abstract}

\section{Introduction}

Fossil fuel scarcity risks constraining human development $[1,2]$. Uneven distribution of fossil energy resources can increase the risk [2]. Moreover, climate change and environmental issues also call for a more efficient energy policy $[3,4,5]$.

Distributed generation or local power supply systems may be one of the solutions for solving environmental and energy issues $[6,7,8]$. Biomass based power plants could be the solution to the regions that suffer from energy scarcity and harmful emissions [2, 6]. The widespread development of bioenergy is a factor for the sustainability of the power supply systems.

To mitigate climate changes and to ensure energy security, the European Union (EU) is promoting bioenergy. According to a new EU energy strategy, the targets for 2030 include at least $27 \%$ of energy to be delivered from renewable sources [9]. It reduces greenhouse gas (GHG) emissions by $40 \%$ compared to the levels of 1990 [10]. The energy and climate policies in the EU have encouraged the development of biomass-based power generation. Unlike solar or wind power, biomass based power plants provide a reliable energy supply. Currently, biomass provides $13 \%$ of the world's energy consumption. Biomass supply from agriculture is about $61 \%$ of the total organic feedstock $[11,12]$. Therefore, the use of biomass for energy production is of significant parts of reaching the above.

Agriculture may be a supplier of green energy. The term agricultural feedstock encompasses energy crops, agricultural residues and animal waste. The main types of biomass used for electricity production are the following: woody crops (oxytree, willow, etc.); energy crops (sorghum, maize silage, etc.); straw; manure; etc. Woody crops and straw are directly combusted in thermal power plants. Energy crops, straw, and manure, can be used as a substrate for biogas plants.

Some research papers have dealt with biomass energy and environmental performance for power generation [13, $14,15,16]$. However, integrated analysis for agricultural residue based power supply systems is still absent. Thus, the energy analysis of agricultural residue does not take into account all kinds of energy consumption (direct, indirect, manufacturing, and assembly energy requirements for agricultural tractors, machinery, etc.) $[17$, $18]$.

The purpose of this study is to develop a life cycle assessment model for the energy and environmental (greenhouse gas emission) performance of straw production (from the seeding of crop to utilization).

\section{Methodology}

The agricultural feedstock data (energy crops, crop residues, process-based residue, livestock manure) is presented in tons. Residue quantity is calculated based on the yields and Residue to Crop Ratio ( $R C R$ ). The yield of straw is equal to

$$
Y_{s}=Y g \cdot R C R, \mathrm{~kg} / \mathrm{ha},
$$

where $Y g$ is the yield of a certain crop, $\mathrm{kg} / \mathrm{ha} ; R C P$ is the Residue to Crop Ratio of a certain crop.

Crop yields are available in Statistical Yearbooks. At the same time, information about residue yields is not collected. The information about Residue to Crop Ratios was summarized by Scarlat et al., Bentsen et al., Cardoen 
et al., and Geletukha et al. [19, 20, 21, 22]. The residueto-crop ratios range from 0.8 to 3.4 . The residue removal rates vary from 15 to $82 \%[19,22,23,24,25]$. Their values depend on a lot of factors.

The Well-to-Wall (WTW) analysis is planned to study the energy supply systems [17]. This method takes into account all the stages of a fuel life cycle. The WTW analysis for biomass considers the impact of the following: crop cultivation, biomass storage, biomass transportation, biomass processing, and biomass utilization in power plants. This method for agricultural residues is planned to be developed.

The WTW and LCA analysis focus on the total primary energy harvested or cumulative energy demand (CED). The cumulative energy demand represents direct and indirect energy use throughout the life cycle. It includes the energy consumed from the extraction to burning. CED is calculated by the following formula

$$
C E D=\sum_{i=1}^{n} E C_{i}, \quad \mathrm{MJ} / \mathrm{kg},
$$

where $E_{i}$ is the energy consumption at $i^{\text {th }}$ stage, $\mathrm{MJ} / \mathrm{kg} ; n$ is the number of stages.

In our calculation, we factored in emissions from fuel supply pathways. It is a so-called well-to-tank (WTT) emissions. Its value was determined by using information about tillage technologies. Therefore, WTT depends on technology applied for crop cultivation.

The environmental and energy impacts of human labor were not considered. All the technological processes included to the life cycle analysis are presented in Figure 1.

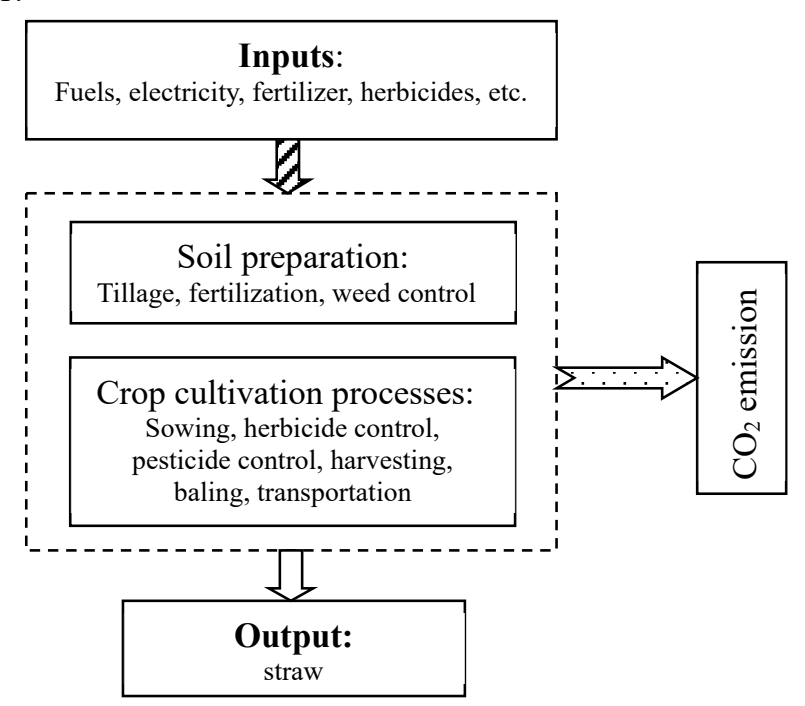

Fig1. The system boundaries for the straw production

\section{Results}

The input energy forms harvest both grains and straw. This energy needs to be shared into two parts: grain and straw. We suggest doing this by the amount of energy in each part of the harvest. The total harvest energy output comprises the energy of grain and the energy of straw.

$$
E H=E G+E S, \mathrm{MJ} / \mathrm{ha},
$$

where $E G$ is the energy content of the grain, $\mathrm{MJ} / \mathrm{ha}$; $E S$ is the energy content of straw, $\mathrm{MJ} / \mathrm{ha}$.

Then the following amount of energy is used on the formation of straw

$$
E S F=\frac{E S}{E H} \cdot \operatorname{Ein}, \mathrm{MJ} / \mathrm{ha},
$$

where Ein is the total input energy, $\mathrm{MJ} / \mathrm{ha}$.

The share of energy which is used to form the straw is

$$
S R=\frac{E S}{E S+E G}=\frac{Y_{g} \cdot R C R \cdot L H V S}{Y_{g} \cdot R C R \cdot L H V S+Y_{g} \cdot L H V g},
$$

where $L H V s$ is the lower heating value of straw, $\mathrm{MJ} / \mathrm{kg}$; $L H V g$ is the lower heating value of grain, $\mathrm{MJ} / \mathrm{kg}$.

After transformation of (5) we obtain the following equation

$$
S R=\frac{R C R \cdot L H V S}{R C R \cdot L H V S+L H V g} .
$$

To evaluate the energy indicators, primary properties of biomass feedstock were used (Table 1).

Table1. Properties of selected crop residues

\begin{tabular}{|l|c|c|c|}
\hline \multicolumn{1}{|c|}{ Crop } & $\begin{array}{c}\text { Lower } \\
\text { heating } \\
\text { value, MJ/kg }\end{array}$ & $\begin{array}{c}\text { Bulk density, } \\
\mathrm{kg} / \mathrm{m}^{3}\end{array}$ & References \\
\hline Wheat & 17.2 & $20-60$ & {$[26]$} \\
\hline Barley & 15.9 & $54-78$ & {$[26]$} \\
\hline Rapeseed & 15.3 & $33-67$ & {$[26]$} \\
\hline Soybean & 15.9 & $27-43$ & {$[26]$} \\
\hline Corn stalk & $8-17$ & $35-80$ & {$[27]$} \\
\hline $\begin{array}{l}\text { Sunflower } \\
\text { stalk }\end{array}$ & 16 & 112 & {$[28]$} \\
\hline
\end{tabular}

The share of energy that is used to form the straw depends on crop type and $R C R$. Scarlat et al. [29] provided the $R C R$ per crop type: rye - from 0.91 to 1.75 ; oats - from 0.91 to 2.0 ; summer wheat - from 0.9 to 1.7 ; winter wheat - from 0.8 to 1.8 ; barley - from 0.9 to 1.8 ; rapeseed -1.0 to 1.7 ; corn - from 0.8 to 2.0 ; rice - from 0.8 to 2.3 . The share of energy ranges from 0.41 to 0.66 (Figure 2). This value shows the share of input energy was used to form the straw.

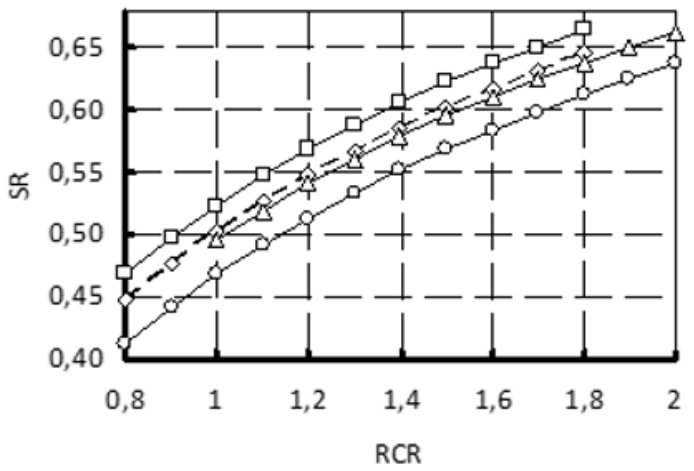

$$
\begin{array}{ll}
-\checkmark-\text { wheat } & \square \text { barley } \\
\longrightarrow & - \text { corn }
\end{array}
$$

Fig2. The share of energy associated with straw

The total energy input comprises direct, indirect and investment energy consumptions

Einput $=$ Edirect + Eindirect + Ema, $\mathrm{MJ} / \mathrm{ha}$, 
where Edirect is the direct energy input (fuels, electricity, etc.), MJ/ha; Eindirect is the indirect energy inputs (technological materials such as fertilizer, herbicides, pesticides, etc.), MJ/ha; Ema is the manufacturing and assembly energy required for tractors and implements, $\mathrm{MJ} / \mathrm{ha}$.

The energy required in manufacturing agricultural implements and tractors were used in this analysis. These values are based on their weight [30]. The same goes for fertilizers. Primary energy consumption and carbon dioxide emission are presented in Table 2.

Table2. Burdens for producing the main types of fertilizers and machines $[31,32]$

\begin{tabular}{|l|c|c|}
\hline $\begin{array}{c}\text { Fertilizer, } \\
\text { machine }\end{array}$ & $\begin{array}{c}\text { Primary energy } \\
\text { consumption, } \\
\mathrm{MJ} / \mathrm{kg}\end{array}$ & $\begin{array}{c}\text { Carbon dioxide } \\
\text { emission, } \\
\mathrm{kgCO}_{2} / \mathrm{kg}\end{array}$ \\
\hline Nitrogen & $29.8-51.6$ & $0.98-2.49$ \\
\hline Phosphate & 13.0 & $1.0-1.6$ \\
\hline Potash & 10.06 & 0.58 \\
\hline Tractor & 51.55 & 4.77 \\
\hline Implement & & \\
\hline
\end{tabular}

Specific carbon dioxide emissions depend on fuel consumption, the carbon content in the fuel, and well-totank emissions. For standard diesel fuel, WTT $\mathrm{CO}_{2}$ emissions are within the range vary from 6.7 to 24 $\mathrm{gCO}_{2} / \mathrm{MJ}$ [33] or from 0.284 to $1.020 \mathrm{kgCO}_{2} / \mathrm{kg}$. Therefore, Well-to-Wheel, carbon dioxide emissions associated with diesel fuel application is calculated by the formula

$$
W T W=B \cdot\left(C C \cdot \frac{11}{3}+W T T e\right), \mathrm{kg} / \mathrm{ha},
$$

where $B$ is the fuel consumption for crop growing, $\mathrm{kg} / \mathrm{ha}$; $C C$ is the carbon content in the fuel, $\mathrm{kg} / \mathrm{kg}$; WTTe is the well-to-tank carbon dioxide emissions for any fuel, $\mathrm{kgCO}_{2} / \mathrm{kg}$.

Carbon dioxide emissions from electricity consumed is $[34,35]$

$$
C D E E=E T C \cdot E F c, \mathrm{kgCO}_{2} / \mathrm{ha},
$$

where $E T C$ is the electricity consumption for crop growing, $\mathrm{kWh} / \mathrm{ha} ; E F c$ is the emission factor from grid electricity, $\mathrm{kgCO}_{2} / \mathrm{kWh}$.

During fertilizer production, there is energy consumption. It results in carbon dioxide emissions which is computed by the following expression

$$
C D F=\sum_{i=1}^{n}\left(M F_{i} \cdot C D E_{i}\right), \mathrm{kg} / \mathrm{ha},
$$

where $M F_{i}$ is the consumption of $i^{\text {th }}$ fertilizer, $\mathrm{kg} / \mathrm{ha} ; C D E_{i}$ is the carbon dioxide emissions during the production process of $i^{\text {th }}$ fertilizer, $\mathrm{kgCO}_{2} / \mathrm{kg}$.

We have considered the application of this approach using the example of growing wheat in Ukraine by conventional technology. The results of our calculations are the following. Cumulative energy consumption for straw production is $6364 \mathrm{MJ} / \mathrm{ha}$ or $1238.74 \mathrm{MJ} / \mathrm{t}$ (Table 3 ). This value is equal to approximately $10 \%$ of the calorific value of straw and, therefore, must be taken into account in the energy assessment of biomass power plants.
Table3. Cumulative energy consumption for straw production

\begin{tabular}{|l|c|r|}
\hline \multicolumn{1}{|c|}{ Parameter } & Unit & \multicolumn{1}{c|}{ Value } \\
\hline Total energy consumption: & $\mathrm{MJ} / \mathrm{ha}$ & 11655.69 \\
\hline Direct & $\mathrm{MJ} / \mathrm{ha}$ & 3767.63 \\
\hline Indirect & $\mathrm{MJ} / \mathrm{ha}$ & 6056.01 \\
\hline $\begin{array}{l}\text { Energy required in } \\
\text { manufacturing agricultural } \\
\text { implements and tractors }\end{array}$ & $\mathrm{MJ} / \mathrm{ha}$ & 1832.05 \\
\hline Yield of grain & $\mathrm{t} / \mathrm{ha}$ & 4.11 \\
\hline Yield of straw & $\mathrm{t} / \mathrm{ha}$ & 5.138 \\
\hline $\begin{array}{l}\text { The share of energy which is used } \\
\text { to form the straw }\end{array}$ & - & 0.546 \\
\hline $\begin{array}{l}\text { The energy which is used to form } \\
\text { the straw }\end{array}$ & $\mathrm{MJ} / \mathrm{ha}$ & 6364.00 \\
\hline & $\mathrm{MJ} / \mathrm{t}$ & 1238.74 \\
\hline
\end{tabular}

Ecological footprint has been computed too (Figure 3).

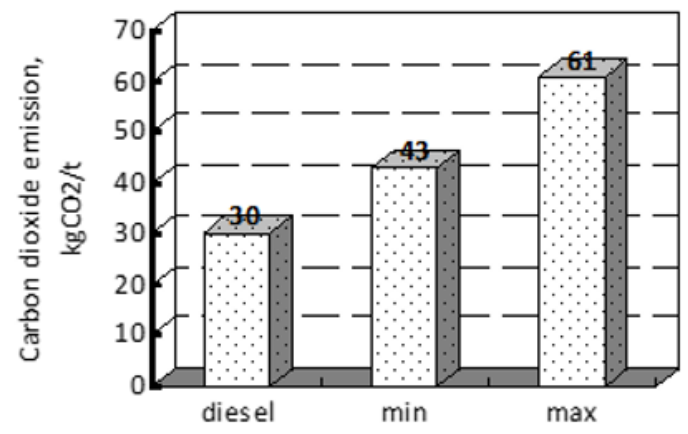

Fig3. Ecological footprint

The carbon dioxide emissions for straw production vary from 43 to $61 \mathrm{kgCO}_{2} / \mathrm{t}$. Accounting for the use of fertilizers, herbicides, and agricultural machinery increases the $\mathrm{CO}_{2}$ emissions by $50-100 \%$ compared to diesel fuel utilization. Therefore, it is necessary to take into account the indirect energy consumption when performing environmental analysis.

\section{Conclusion}

Renewable energy sources, including cereal straw, are a priority of green power generation on the local levels. Therefore, a life cycle energy and greenhouse gas emissions analysis of straw is of great importance.

The model for determining cumulative energy consumption and Well-to-Tank carbon dioxide emissions for straw production (from seed sowing to harvesting) has been developed. It has been found that the share of energy consumed by straw formation is within the range from 41 to $66 \%$ (for wheat production in conditions of Ukraine). It is around $10 \%$ of its calorific value. Carbon dioxide emissions vary from 43 to $61 \mathrm{~kg} / \mathrm{t}$. Therefore, the above indicators are significant and must be taken into account when analyzing straw-based power plants.

\section{References}

1. I. Capellán-Pérez, M. Mediavilla, C.D. Castro, Ó. Carpintero, L.J. Miguel, Fossil fuel depletion and 
socio-economic scenarios: An integrated approach. Energy 77, 641-666 (2014).

2. N. Bauer, J. Hilaire, R.J. Brecha, J. Edmonds, K. Jiang, E. Kriegler, H. Rogner, F. Sferra, Assessing global fossil fuel availability in a scenario framework, Energy 111, 580-592 (2016).

3. P.J. Landrigan, R. Fuller, Global health and environmental pollution. Int. J. Public Health 60, 761-762 (2015).

4. C. Mcglade, P. Ekins, The geographical distribution of fossil fuels unused when limiting global warming to $2{ }^{\circ} \mathrm{C}$. Nature $517,187-190$ (2015).

5. Y. Tan, Toward a law of healthy peoples: From the Perspective of the Right to Health. Future Human Image 13, 113-125 (2020).

6. S. Mallikarjun, H.F. Lewis, Energy technology allocation for distributed energy resources: A strategic technology-policy framework. Energy 72, 783-799 (2014).

7. O. Bazaluk, V. Havrysh, V. Nitsenko, T. Baležentis, D. Streimikiene, E.A. Tarkhanova, Assessment of Green Methanol Production Potential and Related Economic and Environmental Benefits: The Case of China. Energies 13(12), 3113 (2020).

8. T. Melnyk, Ukraine and Its Future in a Globalised International Community. Ukrainian Policymaker 3, 17-28 (2018).

9. A Policy Framework for Climate and Energy in the Period from 2020 to 2030, European Commission, Brussels (2014).

10. N. Scarlat, M. Martinov, J.-F. Dallemand, Assessment of the availability of agricultural crop residue in the European Union: Potential and limitations for bioenergy use. Waste Management 30, 1889-1897 (2010).

11. J. Popp, S. Kovács, J. Oláh, Z. Divéki, E. Balázs, Bioeconomy: Biomass and biomass-based energy supply and demand. New Biotechnology 60, 76-84 (2021).

12. Rada Ministrów, Polityka energetyczna Polski do 2030 r. (2009).

13. A. Vatsanidou, C. Kavalaris, S. Fountas, N. Katsoulas, T. Gemtos, A Life Cycle Assessment of Biomass Production from Energy Crops in Crop Rotation Using Different Tillage System. Sustainability 12, 6978 (2020).

14. S. Kim, B.E. Dale, Life cycle assessment of various cropping systems utilized for producing biofuels: Bioethanol and biodiesel. Biomass and Bioenergy 29, 426-439 (2005).

15. B. Küsterman, J.C. Munch, K.J. Hólsbergen, Effects of soil tillage and fertilization on resource efficiency and greenhouse gas emissions in a long-term field experiment in Southern Germany. Eur. J. Agron. 49, 61-73 (2015).

16. Y. Jiang, V. Havrysh, O. Klymchuk, V. Nitsenko, T. Balezentis, D. Streimikiene, Utilization of Crop Residue for Power Generation: The Case of Ukraine.
Sustainability 11(24), 7004 (2019).

17. X. Ou, Y.Xiaoyu, X. Zhang, Life-cycle energy consumption and greenhouse gas emissions for electricity generation and supply in China. Applied Energy 88, 289-297 (2011).

18. D. Weisser, A guide to life-cycle greenhouse gas (GHG) emissions from electric supply technologies. Energy 32, 1543-59 (2007).

19. N.S. Bentsen, C. Felby, B.J. Thorsen, Agricultural residue production and potentials for energy and materials services. Progress in Energy and Combustion Science 40, 59-73 (2014).

20. N. Scarlat, M. Martinov, J.-F. Dallemand, Assessment of the availability of agricultural crop residue in the European Union: Potential and limitations for bioenergy use. Waste Management 30, 1889-1897 (2010).

21. D. Cardoen, P. Joshi, L. Diels, P.M. Sarma, D. Pant, Agriculture biomass in India: Part 1. Estimation and characterization. Resources, Conservation and Recycling 102, 39-48 (2015).

22. G. Geletukha, T. Zheliezna, Prospects for the use of agricultural residue for energy production in Ukraine. UABio Position Paper 7 (2014).

23. F. Monforti, K. Bódis, N. Scarlat, J.-F. Dallemand, The Possible Contribution of Agricultural Crop Residue to Renewable Energy Targets in Europe: A Spatially Explicit Study. Renewable and Sustainable Energy Reviews 19(0), 666-677 (2013).

24. C. Weiser, V. Zeller, F. Reinicke, B. Wagner, S. Majer, A. Vetter, D. Thraen, Integrated assessment of sustainable cereal straw potential and different strawbased energy applications in Germany. Applied Energy 114, 749-762 (2014).

25. M. De Noord, L.W.M. Beurskens, H.J. De Vries, Potentials and costs for renewable electricity production. A data Overview 2004. ECN-C 03-006 (2004).

26. P. Adapa, L. Tabil, G. Schoenau, Grinding performance and physical properties of non-treated and steam-exploded barley, canola, oat, and wheat straw. Biomass and Bioenergy 35, 549-561 (2011).

27. Physico-mechanical properties of corn $(\mathrm{n} / \mathrm{d})$.

28. M.-A. Perea-Moreno, F. Manzano-Agugliaro, A.J. Perea-Moreno, Sustainable Energy Based on Sunflower Seed Husk Boiler for Residential Buildings. Sustainability 10, 3407 (2018).

29. N. Scarlat, M. Martinov, J.-F. Dallemand, Assessment of the availability of agricultural crop residues in the European Union: Potential and limitations for bioenergy use. Waste Management 30, 1889-1897 (2010).

30. M.C. Heller, G.A. Keoleian, T.A. Volk, Life cycle assessment of a willow bioenergy cropping system. Biomass and Bioenergy 25, 147-165 (2003).

31. M. Skowroñska, T. Filipek, Life cycle assessment of fertilizers: a review. Int. Agrophys. 28, 101-110 (2014). 
32. J. Lee, H. Cho, B. Choi, J. Sung, S. Lee, M. Shin, Life cycle assessment of tractors. Int. J. LCA 5, 205208 (2000).

33. M. Eriksson, S. Ahlgren, LCAs of Petrol and Diesel-A Literature Review (Swedish University of Agricultural Science: Uppsala, Sweden, 2013).

34. V. Havrysh, A. Kalinichenko, G. Mentel, U. Mentel, D.G. Vasbieva, Husk Energy Supply Systems for Sunflower Oil Mills. Energies 13, 361 (2020).

35. V. Havrysh, V. Hruban, O. Sadovoy, A. Kalinichenko, K. Taikhrib, Sustainable Energy Supply Based on Sunflower Seed Husk for Oil mills. Proceedings of the International Conference on Modern Electrical and Energy Systems, MEES (2019). 